\title{
Life cycle assessment as a tool to evaluate the impact of reducing crude protein in pig diets
}

\author{
Alessandra Nardina Trícia Rigo Monteiro ${ }^{1,2}$ Jean-Yves Dourmad ${ }^{3}$ Paulo Cesar Pozza $^{2^{*}}$ \\ ${ }^{1}$ Coordenação de Aperfeiçoamento de Pessoal de Nível Superior (CAPES), Brasília, DF, Brasil. \\ ${ }^{2}$ Departamento de Zootecnia, Universidade Estadual de Maringá (UEM), Avenida Colombo, 5790, 91540-000, Maringá, PR, Brasil. \\ E-mail: pcpozza@uem.br. "Corresponding author. \\ ${ }^{3}$ Unité Mixte de Recherche 1348 Pegase, Domaine de la Prise, 35590, Saint-Gilles, France.
}

ABSTRACT: Environmental impacts of livestock systems, especially pig production, have come under increasing debate in recent years. The challenge is in meeting the growing demand for food at an affordable cost, without compromising environmental integrity. Previous studies have shown that feed production is responsible for the majority of $\mathrm{CO}_{2}$-eq. emission resulting from pig farming systems. This seems to indicate that feed strategies could be an effective tool to achieve the sustainability of the pork chain. Therefore, dietary crude protein reduction, through the addition of industrial amino acids, lessens the nitrogen excretion by pigs and, consequently, could mitigate the effects on the environment of pig production. In this sense, to effectively evaluate the environmental impacts of pig production systems, life cycle assessment has been widely used in agriculture, but the effects of feed are still understudied in Brazilian conditions. Owing to the importance and the great concern in this research area, we presented in this paper an updated review focusing on the nutritional techniques and their potential to reduce the global warming potential of pig production, considering both the direct effects, related to the choice of feed ingredients and the indirect effects, related to changes in the efficiency of use of nutrient by the animals.

Key words: crude protein, environmental impact, global warming potential, greenhouse gases, nutrient.

Análise do ciclo de vida como ferramenta para avaliar o impacto da redução do conteúdo de proteína bruta da dieta de suínos

RESUMO: O impacto ambiental da produção animal, especialmente da suinocultura, vêm sendo objeto de crescente debate nos últimos anos. O desafio é atender a crescente demanda por alimentos a um custo acessivel, mas sem comprometer a integridade ambiental. Estudos vêm demonstrando que a produçao de rações é responsável pela maior parte das emissões de $\mathrm{CO}_{2}$-eq. do sistema de produção de suínos. Isso parece indicar que estratégias de alimentação podem ser ferramentas eficientes para alcançar a sustentabilidade da cadeia suinícola. Dessa forma, a redução do conteúdo de proteína bruta da dieta através da inclusão de aminoácidos industriais, leva à diminuição da excreção de nitrogênio em suínos e, consequentemente, pode mitigar o impacto ambiental do sistema de produção de suínos. Neste sentido, para avaliação efetiva do impacto ambiental do sistema produtivo, a análise do ciclo de vida vem sendo amplamente utilizada na agricultura, mas os efeitos da alimentação ainda são pouco estudados nas condições brasileiras. Devido a importância e a grande preocupação nesta área de pesquisa, este artigo trás uma revisão atualizada com foco nas técnicas de nutrição e principalmente no seu potencial em reduzir o potencial de aquecimento global da produção de suínos, considerando ambos os efeitos diretos, relacionados à escolha dos ingredientes da ração, e os efeitos indiretos, relacionados às mudanças na eficiência de uso de nutrientes pelos animais.

Palavras-chave: proteína bruta, impacto ambiental, potencial de aquecimento global, gases de efeito estufa, nutrição.

\section{INTRODUCTION}

According to the Food and Agriculture Organization (FAO), the world population will rise to 9.1 billion in the year 2050 , representing a $21 \%$ increase compared to 2010 (ALEXANDRATOS \& BRUINSMA, 2012). In this scenario, the challenge for livestock production, and especially for pig production, will be to meet the growing demand for food at an affordable cost, without compromising environmental integrity. Therefore, special attention has to be focused on the rational use of natural resources and the term "sustainable agriculture" is a target in national and international discussions about the future of the planet.
The pig supply chain involves a complex system, starting with the production of resources such as fertilizers and pesticides, until the disposal of animal waste including their reuse as fertilizers (McAULIFFE et al., 2016). Pig production system is responsible for air methane $\left(\mathrm{CH}_{4}\right)$, ammonia $\left(\mathrm{NH}_{3}\right)$ and nitrous oxide $\left(\mathrm{N}_{2} \mathrm{O}\right)$ emissions, as well as risks of water and soil contamination resulting from inefficient manure management practices (McAULIFFE et al., 2016).

Life cycle assessment (LCA) has been widely used in agriculture (GUINÉE et al., 2002) and pig production (McAULIFFE et al., 2016), to evaluate environmental impacts at global scale, such as global warming potential (GWP), resources depletion and ozone depletion, or at regional and local scale, such as 
terrestrial ecotoxicity, acidification potential (AP) and eutrophication potential (EP) (GUINÉE et al., 2002).

In the literature, improvement of nutritional strategy and manure management practices has been widely investigated in order to achieve a pig production with low carbon emission. In this article, we will focus on the nutritional techniques and mainly their potential to reduce the GWP of pig production, considering both the direct effects related to the choice of feed ingredients and the indirect effects related to changes in the efficiency of use of nutrient by the animals. However, because of concern about nitrogen $(\mathrm{N})$ and phosphorus $(\mathrm{P})$ excretion by pigs and their use as fertilizers, other environmental impact categories will also be discussed, like AP and EP.

\section{Nutritional strategies as a tool for sustainable pork production}

For more than 50 years, when the ideal protein concept was established (MITCHELL, 1964), the possible reduction of dietary crude protein $(\mathrm{CP})$ has continously been investigated with the aim of reducing feed costs or, more recently, $\mathrm{N}$ excretion. The strategy was to better match amino acid (AA) requirements and consequently, reduce dietary $\mathrm{N}$ excess.

Dietary proteins are hydrolyzed into individual AA in the gastrointestinal tract (NELSON \& COX, 2012). These AA are transported through the epithelial and reach the liver. Some AA are metabolized in different metabolic ways, such as the citric acid cycle, as glucose precursors (NELSON \& COX, 2012) and for body protein synthesis (WEINER et al., 2015). The non-digestible AA are excreted in faeces, and those absorbed, but not used in a specific function, are metabolized in the liver and $\mathrm{N}$ waste is excreted in the urine (NRC, 2012).

According to this principle, and as reviewed by DOURMAD \& JONDREVILLE (2007), reducing the dietary $\mathrm{CP}$ while balancing the diet with feed-use (FU) AA is an effective way of reducing $\mathrm{N}$ excretion, as long as pig performance and carcass composition are not adversely affected. These authors reported about $9 \%$ reduction in $\mathrm{N}$ excretion by growingfinishing pigs per percentage unit of $\mathrm{CP}$ reduction, when the dietary CP level was reduced from 178 to $136 \mathrm{~g} \mathrm{~kg}^{-1}$, without affecting energy efficiency, carcass lean percentage or average daily gain.

Indeed, reducing $\mathrm{N}$ excretion could be an efficient way of reducing the amounts of reactive $\mathrm{N}$, consequently reducing the environmental burdens, since $\mathrm{N}$ contributes to the eutrophication process, as well as to the acidification process by ammonia emissions (GUINÉE et al., 2002). Nitrogen excretion contributes to the emission of greenhouse gases (GHG) emissions due to direct emissions of $\mathrm{N}_{2} \mathrm{O}$ from manure (RIGOLOT et al., 2010b) and indirect emissions associated with the deposition of $\mathrm{NH}_{3}$ and the spreading of manure as fertilizer (IPCC, 2006). Reducing the dietary CP also modifies the rate of incorporation of the different feed ingredients, especially protein sources, affecting the impacts of several stages in the pig production system. To effectively evaluate the environmental impacts of food production systems, life cycle assessment (LCA) has been widely used in agriculture (GUINÉE et al., 2002) and several studies of swine production chains have been conducted (Table 1), as reviewed by McAULIFFE et al. (2016).

Concerning the effect of pig feeding, most of these LCA studies indicated that reducing dietary $\mathrm{CP}$ is one of the most effective nutritional strategies that contribute to improve the environmental performance in the pig production chain, especially concerning GWP, AP and EP (VAN DER WERF et al., 2005; MOSNIER et al., 2011; GARCIA-LAUNAY et al., 2014). It appears that reducing dietary CP modifies the environmental impacts at several stages of pig production, since the $\mathrm{N}$ content of manure and gaseous $\mathrm{N}$-emissions during storage, treatment and field application, are related to $\mathrm{N}$ intake. In that perspective, the most common approach investigated in the literature is the reduction of dietary $\mathrm{CP}$ with the use of industrial AA. This results in a decrease in the incorporation of protein-rich feed ingredients, such as soybean meal, and their replacement by cereals and industrial AA.

\section{Nutrition and global warming potential.}

The concept of GWP was developed to allow the comparison of the global warming impacts of different GHG. It is generally expressed in $\mathrm{kg}$ equivalent $\mathrm{CO}_{2}$. According to the International Panel on Climate Change (IPCC 2007), in a 100-year time horizon, nitrous oxide $\left(\mathrm{N}_{2} \mathrm{O}\right)$ and $\mathrm{CH}_{4}$ emissions have 298 times and 25 times the GWP of $\mathrm{CO}_{2}$, respectively.

In the production chain the emissions of GHG originate from several processes. Fossil energy and electricity used for the synthesis of fertilizers and for crop production, for the mixing and pelleting of complete feed, for animal housing and manure management, and for the processing and transportation of pork products, are responsible for $\mathrm{CO}_{2}$ emissions from pig production (GILL et al., 2010). Methane emissions occur from enteric fermentation in farm animals (RIGOLOT et al., 2010a) and manure management in pig operations 
Table 1 - Effect of feeding strategy on global warming potential (GWP), eutrophication (EP) and acidification (AP) of different pig production systems.

\begin{tabular}{|c|c|c|c|c|c|c|c|}
\hline Study & Country & Functional unit & Feed & Dietary CP & GWP & EP & $\mathrm{AP}$ \\
\hline & & & & $\mathrm{g} / \mathrm{kg}$ & $\mathrm{kg} \mathrm{CO}_{2}$-eq. & $\mathrm{g} \mathrm{PO}_{4}$-eq. & $\mathrm{g} \mathrm{SO}_{2}$-eq. \\
\hline \multirow[t]{3}{*}{$\begin{array}{l}\text { 1. BASSET-MENS and } \\
\text { van der WERF (2005) }\end{array}$} & France & $\mathrm{kg}$ of pig & Conventional & & 2.30 & 20.8 & 43.5 \\
\hline & & & Red label & & 3.46 & 16.6 & 22.6 \\
\hline & & & Organic & & 3.97 & 21.6 & 37.2 \\
\hline \multirow[t]{3}{*}{$\begin{array}{l}\text { 2. ERIKSSON et al. } \\
(2005)\end{array}$} & Sweden & kg pig & Soy & 147.0 & 1.51 & & 24.3 \\
\hline & & & Pea & 155.0 & 1.36 & & 25.4 \\
\hline & & & Mix- withAA & 137.0 & 1.39 & & 19.5 \\
\hline \multirow[t]{2}{*}{$\begin{array}{l}\text { 3. LAMMERS et al. } \\
(2010)\end{array}$} & US & One marketed pig & Conventional & & 218 & & \\
\hline & & & Hoop barn & & 142 & & \\
\hline \multirow[t]{2}{*}{ 4. OGINO et al. (2013) } & Japan & $\mathrm{kg}$ liveweight & Conventional & 155.5 & 3.16 & 9.1 & 21.7 \\
\hline & & & lowCP & 126.5 & 2.99 & 6.6 & 20.7 \\
\hline \multirow[t]{6}{*}{$\begin{array}{l}\text { 5. GARCIA-LAUNAY } \\
\text { et al. (2014) }\end{array}$} & France & kg BW & Soy- noAA & 180.0 & 2.68 & 21.2 & 53.2 \\
\hline & & & Soy- withAA & 132.0 & 2.31 & 16.9 & 36.6 \\
\hline & & & Soy- lowCP & 123.0 & 2.26 & 16.5 & 34.6 \\
\hline & & & Mix- noAA & 169.0 & 2.41 & 21.6 & 48.3 \\
\hline & & & Mix- withAA & 133.0 & 2.22 & 16.8 & 36.9 \\
\hline & & & Mix- lowCP & 123.0 & 2.26 & 16.5 & 34.6 \\
\hline \multirow[t]{4}{*}{$\begin{array}{l}\text { 6. CHERUBINI et al. } \\
(2015 b)\end{array}$} & Brazil & kg BWG & CP18 & 179.5 & 2.35 & & \\
\hline & & & CP16 & 164.5 & 2.24 & & \\
\hline & & & CP15 & 149.5 & 2.29 & & \\
\hline & & & $\mathrm{CP} 13$ & 134.5 & 2.53 & & \\
\hline $\begin{array}{l}\text { 7. CHERUBINI et al. } \\
(2015 \mathrm{a})\end{array}$ & Brazil & $\mathrm{kg}$ pig carcass & Conventional & 175.3 & 3.10 & & 0.076 \\
\hline \multirow[t]{5}{*}{$\begin{array}{l}\text { 8. MACKENZIE et al } \\
(2016)\end{array}$} & Canada & $\mathrm{kg}$ pig carcass & Control & 132.6 & 2.20 & 14.4 & 57.4 \\
\hline & & & Meat meal & 146.9 & 2.16 & 15.8 & 61.6 \\
\hline & & & DDGS & 138.4 & 2.55 & 14.3 & 56.5 \\
\hline & & & Wheat shorts & 135.0 & 1.95 & 16.6 & 56.9 \\
\hline & & & Bakery meal & 132.2 & 2.13 & 14.1 & 55.8 \\
\hline \multirow[t]{3}{*}{$\begin{array}{l}\text { 9. MONTEIRO et al. } \\
(2016 b)\end{array}$} & Brazil & kg BWG & noAA & 160.1 & 2.37 & 62.4 & 18.6 \\
\hline & & & withAA & 149.4 & 2.39 & 60.6 & 17.9 \\
\hline & & & lowCP & 126.5 & 2.45 & 55.1 & 16.1 \\
\hline
\end{tabular}

$\overline{\mathrm{CP}}$, crude protein; BW, body weight; BWG, body weight gain; Soy, feeds based on soybean meal; Mix, feeds based on soybean meal and grains; noAA, feeds without feed-use amino acids; withAA, feeds with feed-use amino acids and minimum $\mathrm{CP}$ content; lowCP, feeds with feed-use amino acids without CP constraint.

(RIGOLOT et al., 2010b), while $\mathrm{N}_{2} \mathrm{O}$ emissions are mainly associated with manure management and the application and deposition of manure (CHADWICK et al., 2011). Moreover, $\mathrm{N}_{2} \mathrm{O}$ emissions from pig production also come from the use and application of mineral and organic fertilizer for feed production (EICHNER, 1990). All these emissions are finally aggregated into $\mathrm{CO}_{2}$-eq. emissions, which represent the GWP of the process or product.
The GWP of pig production has been addressed in many studies. In the national Brazilian context, CHERUBINI et al. (2015a) evaluated the environmental impact of different manure management systems based on LCA. They reported that the biodigestor for energy purposes had the best environmental performance for almost all the environmental impacts, mainly due to biogas capture and the potential of energy savings. The LCA indicated that the production of one 
$\mathrm{kg}$ of swine carcass emitted about $3.50 \mathrm{~kg} \mathrm{CO}$-eq. into the atmosphere, corresponding to about $2.70 \mathrm{~kg} \mathrm{CO}_{2}$-eq per kg pig live weight. However, there have been few studies on the LCA evaluation of nutritional approaches in Brazil, such as CHERUBINI et al. (2015b) and MONTEIRO et al. (2016a).

Environmental consequences of including industrial AA in pig and broiler feeds in France were evaluated by MOSNIER et al. (2011). They compared diets based on cereals and soybean meal without amino acid (noAA) supplementation, with the incorporation of L-lysine, L-threonine and DLmethionine sources (withAA), and supplemented with AA and lowered $\mathrm{CP}$ contents (lowCP). They observed a reduction of GWP with $6.15,6.01$ and $5.92 \mathrm{~g}$ of $\mathrm{CO}_{2}$-eq. $\mathrm{kg}^{-1}$ of feed for noAA, withAA and lowCP, respectively. This represented only a $4 \%$ reduction in GWP of feed, between the noAA diet and the lowCP diet, but in this study protein sources were not associated with any deforestation process.

Evaluating the environmental impacts of pig production with a conventional or a low $\mathrm{CP}$ diet in a Japanese system, OGINO et al. (2013) reported that the low CP diets resulted in a lower GWP (6\%) per pig produced than conventional diets. This represented a $2 \%$ reduction in the GWP for each percentage unit of $\mathrm{CP}$ content. In this study, since the GWP from AA manufacturing were higher than those from the production of the main feed ingredients, i.e., maize and soybean meal, the observed effects on GWP resulted from the reduction of $\mathrm{N}_{2} \mathrm{O}$ emissions from manure management, mainly from wastewater treatment, which were larger than the GWP increase due to the use of AA. Thus, although AA production may have a higher GPW than crop products, they are responsible for the reduction of $\mathrm{N}$ emissions during pig housing, and a decreased GWP of the whole system was observed.

Another study also assessed the environmental impact of pig production in France, according to several scenarios of AA incorporation. In the same way, as observed in previous studies, GARCIA-LAUNAY et al. (2014) reported that reducing the dietary $\mathrm{CP}$ supply, either by a better adjustment of supplies to requirements, with phase feeding, or by increasing the incorporation of industrial AA, reduced GWP impact by about 3\% for each percentage unit of $\mathrm{CP}$ content reduction. Furthermore, the $\mathrm{CP}$ reduction decreased the required amounts of soybean meals, thus reducing the feed cost in that situation. However, in this study it was considered that $70 \%$ of the soybean meal originated from recently deforested areas. Thus, the decreased incorporation of these protein sources with a high GWP resulted in lower $\mathrm{CO}_{2}$-eq. emissions for the low protein diet.

Indeed, the deforestation process contributes substantially to increasing the absolute values of $\mathrm{CO}_{2}$-eq. emissions, due to the effect of landuse change (LUC) on carbon release as a consequence of the conversion of forest to cropland (PAS2050, 2011). PRUDÊNCIO DA SILVA et al. (2010) assessed the environmental consequences of different chains supplying vegetal protein, associated or not with LUC. They reported that $\mathrm{CO}_{2}$-eq. emissions increased by about $47 \%$ when the protein sources came from deforested areas. For this reason, the replacement with industrial AA and with cereals not associated with deforestation appears more efficient to reduce $\mathrm{CO}_{2}$-eq. emissions.

The GWP of the finishing stage in swine production under four scenarios of dietary CP (18, 16,15 and $13 \%$ ) was calculated by CHERUBINI et al. (2015b). In the evaluation of feed composition, CP18 (no soybean hulls or maize starch) showed the best environmental performance for GWP. However, when evaluating the life cycle of finishing swine, CP16 exhibited better environmental results, due to the better technical indicators by pigs fed with CP16 diet. Authors reported that diet has a direct influence on impact generation, due to the feed composition changing the amount of feed required by the animals, and modifying the characteristics of the manure and consequently the emissions produced.

However, the type of manure management also has a direct effect on GWP impact. GARCIALAUNAY et al. (2014) reported that GWP impacts were higher in the solid manure systems (deep litter) than in slurry systems (slatted floor), ranging from 1.06 to 1.37 and from 0.44 to $0.63 \mathrm{~kg} \mathrm{CO}_{2}$-eq. per $\mathrm{kg}$ live weight, when using least-cost formulations without industrial AA addition and with IAA addition, respectively. The difference of GWP between manure management strategies was due to the higher $\mathrm{N}_{2} \mathrm{O}$ emissions during housing and manure storage in pigs raised on deep litter systems, as reviewed by RECKMANN et al. (2012).

A recent study evaluated the LCA of pig production under different scenarios of incorporation of industrial AA (MONTEIRO et al., 2016b). They considered the process of pig fattening in the South Region of Brazil, including the production and transport of feed ingredients and complete feeds, as well as the rearing of pigs and manure management. Different levels of AA incorporation were evaluated: no AA addition (noAA), AA addition with fixed 
$\mathrm{CP}$ content (withAA) and AA addition without $\mathrm{CP}$ constraint (lowCP). Contrasting with previous studies, they reported that when the protein source was produced in a region without deforestation, the incorporation of FU-AA did not appear to be an efficient strategy to reduce the GWP of pig production, since the lowest impact $\left(2.38 \mathrm{~kg} \mathrm{CO}_{2}\right.$-eq. per $\mathrm{kg}$ of body weight gain) was obtained for noAA diets and the highest for low $\mathrm{CP}$ diets $(2.51 \mathrm{~kg} \mathrm{CO}$-eq. per $\mathrm{kg}$ of body weight gain). These results may be associated with the fact that the authors did not consider grain production with any deforestation. Contrasted results could be obtained according to the region considered, such as those obtained by KEBREAB et al. (2016) in Europe, North America and South America, and by MONTEIRO et al. (2016a) in Europe and South America, since the nutritional strategies affected each pig production context differently, and the effect of AA supplementation on the GWP of pig production is highly dependent on the GWP of the protein sources.

Reducing dietary CP content does not always reduce the GWP of the pig chain. The study carried out by MACKENZIE et al. (2016) showed that using meat meal in pig diets increased the dietary $\mathrm{CP}$ compared to a control feed based on maize and soybean meal (147 vs. $133 \mathrm{~g} \mathrm{CP} \mathrm{kg}^{-1}$, respectively). However, the GWP of one $\mathrm{kg}$ of pig carcass was $2 \%$ lower when pigs were fed diets based on meat meal, in a Canadian pig farming system. The benefits of using co-products in pig diets to improve the sustainability of the system are clear, because co-products have their impact allocated from the main product. In this case, meat meal was allocated on an economic basis from meat production for human consumption. Because co-products usually showed lower values than the main product, their environmental impact is low.

\section{Nutrition and acidification and eutrophication potential of pig production}

Acidification potential is related to emissions of acidifing substances into the air, like sulphur oxides, nitrogen oxides (NOx), hydrochloric acid, hydrofluoric acid and $\mathrm{NH}_{3}$. In order to evaluate the acidifying effect of these substances, their acid formation potential (i.e., their ability to form $\mathrm{H}+$ ions) is calculated and set against a reference substance, generally sulphur dioxide equivalent ( $\mathrm{SO}_{2}$-eq.; GUINÉE et al. 2002). Eutrophication potential is related to the emissions of substances that contain $\mathrm{N}$ or $\mathrm{P}$, such as phosphate, nitrate, $\mathrm{NOx}$ and $\mathrm{NH}_{4}$ (GUINÉE et al., 2002). Equivalence factors for each substance are used to convert these emissions into phosphate equivalent ( $\mathrm{PO}_{4}$-eq.; GUINÉE et al., 2002).
The production of feed ingredients contributes to about $50 \%$ of the total AP and EP impacts of pig production (BASSET-MENS \& VAN DE WERF, 2005). MOSNIER et al. (2011) evaluated the effect of reducing dietary $\mathrm{CP}$, with the addition of industrial AA, on AP and EP impacts per $\mathrm{kg}$ feed. Acidification potential and EP impacts were reduced by about $10 \%$ in supplemented compared to nonsupplemented diets with soybean meal as the main protein source. However, in these conditions, the effect was less marked and even non significant for AP, when rapeseed meal and peas were also incorporated as a protein source.

Reducing dietary CP content, by lowering the incorporation of protein-rich ingredients, reduces $\mathrm{N}$ excretion by pigs (TOLEDO et al., 2014; MONTEIRO et al., 2017) and consequently emissions of $\mathrm{NH}_{3}$ and nitrate from manure (VAN DER PEETSCHWERING et al., 1999). A reduction in AP and EP of the pig chain can be expected, when adding AA to the diets, because of the reduction in $\mathrm{NH}_{3}$ and nitrate losses associated with the use of pig manure.

In the study of OGINO et al. (2013) AP and EP per kg of pig produced were reduced by about 2 and $9 \%$, respectively, for each percentage unit of CP content reduction. Likewise, GARCIA-LAUNAY et al. (2014) reported that the reduction of dietary protein content lessened the AP impact by about 5\% and the EP impact by about $3 \%$, for each percentage unit of CP content.

In a Brazilian context, AP and EP were significantly reduced by industrial AA addition and the lowest impact was observed for the lowest CP diets, showing 11 and 13\% decrease in acidification and eutrophication, respectively, compared to diets without AA supplementation (MONTEIRO et al., 2016b). These authors reported that the AP and EP impacts were reduced by about 3 and $4 \%$, respectively, for each percentage unit of CP content, concluding that these categories are highly dependent on $\mathrm{N}$ excretion.

Comparing diets based on meat meal, with dietary CP of $147 \mathrm{~g} \mathrm{~kg}^{-1}$, and diets based on bakery meal, with $132 \mathrm{~g} \mathrm{CP} \mathrm{kg}^{-1}$, AP and EP impacts were reduced by about 6 and $7 \%$, respectively, for each percentage unit of dietary $\mathrm{CP}$ reduction (MACKENZIE et al., 2016). According to KEBREAB et al. (2016), the addition of industrial AA and phytase to pig diets also reduced $\mathrm{EP}$ and $\mathrm{AP}$ in all the regions studied.

\section{DISCUSSION}

Both the concern about natural resources use by livestock and the importance of pork for world meat consumption, have led to the development 
of several studies worldwide, addressing the environmental impact of the swine production chain on GWP, AP and EP (DE VRIES et al., 2013; DOURMAD et al., 2014), particularly in Europe.

The great concern about global warming can be seen by the establishment of annual conferences to discuss the future of the planet. The Conferences of the Parties (COP) organized by the United Nations, is an example, where the partner countries have met annually, since 1995 , to assess progress in dealing with climate change. At the last 2015 edition, the first global climate agreement was defined, i.e., starting in 2020, all countries will be required to reduce their emissions, towards a low carbon economy (COP 2015).

In Brazil, through the Ministério $d a$ Agricultura, Pecuária e Abastecimento, the government proposed the ABC Plan (Low Carbon Agriculture) to be acting in 2010, in order to plan actions to adopt sustainable production technologies (BRASIL, 2012). Pig sector has received considerable attention at the ABC Plan, and from 2015 it became a priority with a special program called "pig production of low carbon emission". This topic aimed to diffuse clean technologies of pig production, encouraging manure treatment and its use as fuels and as fertilizers, as well as financial support to farmers to access technologies of low carbon emissions.

In this context, the evaluation of nutritional techniques as a tool to reduce carbon emissions by Brazilian pig production sectors seems to be a promising research line, mainly because Brazil is the fourth largest producer and exporter of pork in the world (USDA, 2013). However, in a national context, LCA methodology to access the environmental impact of the pig chain is still underused. Since the studies presented in this paper indicated that improving feed efficiency could be an effective way of increasing the sustainability of pig production systems, this approach needs to be more precisely explored in Brazilian conditions of pig production.

Conversely, up to now only a few studies have taken between-animal variability into account (MONTEIRO et al., 2016a). This variability can affect both performance and nutritional requirements (BROSSARD et al., 2014), influencing nutrient excretion and emissions. Moreover, LCA input and output data are usually average values, adding some uncertainties on results. This is especially important in livestock production, due to the huge diversity in production systems and agricultural practices (BASSET-MENS \& VAN DER WERF, 2005), as well as the complexity of interactions among the variables in a LCA study applied to animal production.
Each of these topics showed the need for continued improvement in LCA researches, and three main points could be better explored. The first refers to better taking into account between-animal variability during data estimation, mainly in pig production. The heterogeneity that exists among animals even in groups standardized by age and sex is usually not considered, although different studies have been demonstrating this effect (BROSSARD et al., 2009; VAUTIER et al., 2013). The second refers to the possibility of using experimental data of performance and excretion as inputs and outputs in a LCA study. This could reduce the uncertainties which are assigned to LCA data. The third is related to the validation of estimated LCA data with observed LCA data. This should answer the question if estimated data represent what actually happens in the productive system, related to nutrient excretion and its subsequent emission.

\section{CONCLUSION}

The inclusion of industrial AA to reduce dietary CP content has become a widely studied subject and it appears an efficient approach to reduce environmental burdens, especially for acidification and eutrophication. However, only a limited number of studies have been conducted in Brazilian conditions and some results seem to indicate that the environmental benefit of this technology might depend on the context of production, especially for global warming. Moreover the variability between animals and between farms has received little attention until now and could also interfere with the results. Therefore, addressing the potential environmental impacts of the swine sector under different feeding scenarios, especially in Brazil, is still very important to fill this gap in knowledge.

\section{ACKNOWLEDGEMENTS}

This project was conducted within a sandwich $\mathrm{PhD}$ thesis program supported by Coordenação de Aperfeiçoamento de Pessoal de Nível Superior (CAPES), Brazil.

\section{REFERENCES}

ALEXANDRATOS, N., BRUINSMA, J. World agriculture towards 2030/2050: the 2012 revision. In: DIVISION A.D.E. (Eds.). Food and Agriculture Organization of the United Nations. Rome: FAO, 2012. 154p.

BASSET-MENS C.; VAN DER WERF, H.M.G. Scenariobased environmental assessment of farming systems: the case of pig production in France. Agriculture, Ecosystems and 
Environment, v.105, p.127-144, 2005. Available from: <http:// www.sciencedirect.com/science/article/pii/S0167880904001744>. Accessed: Dec. 07, 2014. doi: 10.1016/j.agee.2004.05.007.

BRASIL - Ministério da Agricultura, Pecuária e Abastecimento. 2012. Plano setorial de mitigação e de adaptação às mudanças climáticas para a consolidação de uma economia de baixa emissão de carbono na agricultura: Plano ABC. Available from: <http://www.agricultura. gov.br/arq_editor/download.pdf $>$. Online. Accessed: Sept. 26, 2016.

BROSSARD, L. et al. Comparison of in vivo and in silico growth performance and variability in pigs when applying a feeding strategy designed by simulation to control the variability of slaughter weight. Animal Production Science, v.54, p.19391945, 2014. Available from: <http://www.publish.csiro.au/AN/ AN14521>. Accessed: Sept. 26, 2016. doi:10.1071/AN14521.

BROSSARD, L. et al. Modelling the variation in performance of a population of growing pig as affected by lysine supply and feeding strategy. Animal, v.3, p.1114-1123, 2009. Available from: $<$ https:// www.ncbi.nlm.nih.gov/pubmed/22444841>. Accessed: Dec. 14, 2014. doi: $10.1017 / \mathrm{S} 1751731109004546$.

CHADWICK, D. et al. Manure management: implications for greenhouse gas emissions. Animal Feed Science and Technology, v.166, p.514-531, 2011. Available from: $<$ http://www.sciencedirect. com/science/article/pii/S0377840111001556>. Accessed: Sept. 20, 2015. doi: 10.1016/j.anifeedsci.2011.04.036.

CHERUBINI, E. et al. Life cycle assessment of swine production in Brazil: a comparison of four manure management systems. Journal of Cleaner Production, v.87, p.68-77, 2015a. Available from: <http:// www.sciencedirect.com/science/article/pii/S0959652614010774>. Accessed: Sept. 15, 2015. doi: 10.1016/j.jclepro.2014.10.035.

CHERUBINI, E. et al. The finishing stage in swine production: influences of feed composition on carbon footprint. Environment, Development and Sustainability, v.17, p.1313-1328, 2015b. Available from: <https://link.springer.com/article/10.1007/s10668-014-9607-9>. Accessed: Sept. 15, 2015. doi: 10.1007/s10668-014-9607-9.

COP (CONFERENCE OF THE PARTIES). Framework convention on climate change. Paris, 2015. 32p.

DE VRIES, J.W. et al. Life cycle assessment of segregating fattening pig urine and feces compared to conventional liquid manure management. Environmental Science \& Technology, v.47, p.1589-1597, 2013. Available from: <https://www.ncbi.nlm.nih.gov/pubmed/23268735>. Accessed: Dec. 14, 2015. doi: 10.1021/es302951a.

DOURMAD J.-Y. et al. Evaluating environmental impacts of contrasting pig farming systems with life cycle assessment Animal, v.8, p.2027-2037, 2014. Available from: <https://www. ncbi.nlm.nih.gov/pubmed/25170767>. Accessed: May. 18, 2014. doi: $10.1017 / \mathrm{S} 1751731114002134$.

DOURMAD, J.-Y.; JONDREVILLE, C. Impact of nutrition on nitrogen, phosphorus, $\mathrm{Cu}$ and $\mathrm{Zn}$ in pig manure, and on emissions of ammonia and odours. Livestock Science, v.112, p.192-198, 2007. Available from: $<$ http:/www.sciencedirect.com/science/article/pii/S1871141307004684>. Accessed: Jan. 11, 2013. doi: 10.1016/j.livsci.2007.09.002.

EICHNER, M.J. Nitrous oxide emissions from fertilized soils: summary of available data. Journal of Environmental Quality, v.19, p.272-280, 1990. Available from: <http://agris.fao.org/agrissearch/search.do?recordID=US9413440>. Accessed: Nov. 13, 2014.
ERIKSSON, I.S. et al. Environmental systems analysis of pig production - the impact of feed choice. International Journal of Life Cycle Assessment, v.10, p.143-154, 2005. Available from: <https://link.springer.com/article/10.1065/lca2004.06.160>. Accessed: Dec. 28, 2015. doi: 10.1065/lca2004.06.160.

GARCIA-LAUNAY, F. et al. Evaluation of the environmental implications of the incorporation of feed-use amino acids in pig production using Life Cycle Assessment. Livestock Science, v.161, p.158-175, 2014. Available from: <http://www.sciencedirect.com/ science/article/pii/S1871141313005209>. Accessed: May. 17, 2014. doi: 10.1016/j.livsci.2013.11.027.

GILL, M. et al. Mitigating climate change: the role of domestic livestock. Animal, v.4, p.323-333, 2010. Available from: <https:// www.ncbi.nlm.nih.gov/pubmed/22443938>. Accessed: Aug. 24, 2016. doi: $10.1017 / \mathrm{S} 1751731109004662$.

GUINÉE, J.B. et al. Handbook on life cycle assessment: operational guide to the ISO standards Netherlands. 2002. doi: 10.1007/0-306-48055-7.

IPCC. Guidelines for National Greenhouse Gas Inventories: Emissions from Livestock and Manure Management. 2006. Available from: http://www.ipcc-nggip.iges.or.jp/public/2006gl/pdf/4_Volume4/ V4_10_Ch10_Livestock.pdf. Accessed: Mar. 10, 2015.

IPCC. Climate change 2007: The Physical Science Basis, 2007. Available from: <https://www.ipcc.ch/pdf/assessment-report/ar4/ wg1/ar4-wg1-frontmatter.pdf>. Accessed: Mar. 10, 2015.

KEBREAB, E. et al. Environmental impact of using specialty feed ingredients in swine and poultry production: a life cycle assessment. Journal of Animal Science, v.94, p.664-681, 2016. Available from: $<$ https://www.ncbi.nlm.nih.gov/pubmed/27285941>. Accessed: Apr. 14, 2016. doi:10.2527/jas.2015-9036.

MACKENZIE, S.G. et al. Can the environmental impact of pig systems be reduced by utilising co-products as feed? Journal of Cleaner Production, v.56, p.12-22, 2016. Available from: <http:// www.sciencedirect.com/science/article/pii/S0959652615018995>. Accessed: Sept. 12, 2016. doi: 10.1016/j.jclepro.2015.12.074.

McAULIFFE, G.A. et al. A thematic review of life cycle assessment (LCA) applied to pig production. Environmental Impact Assessment Review, v.56, p.12-22, 2016. Available from: <http:// www.sciencedirect.com/science/article/pii/S0195925515000839>. Accessed: Sep. 02, 2016. doi: 10.1016/j.eiar.2015.08.008.

MITCHELL, H.H. Comparative nutrition of man and domestic animals. New York: Academic, 1964. 701p.

MONTEIRO, A.N.T.R. et al. Effect of feeding strategy on environmental impacts of pig fattening in different contexts of production: evaluation through life cycle assessment. Journal of Animal Science, v.94, p.4832-4847, 2016a. Available from: <https://www.ncbi.nlm.nih.gov/ pubmed/27898927>. Accessed: Oct. 14, 2016. doi: 10.2527/jas.2016-0529.

MONTEIRO, A.N.T.R. et al. The effect of amino acids utilization on environmental impact of fattening pig production. In: INTERNATIONAL MEETING OF ADVANCES IN ANIMAL SCIENCE, 2016b, Jaboticabal, SP. Proceedings... Jaboticabal. 2016b. Available from: <https:// proceedings.galoa.com.br/imas/papers $>$. Accessed: Sept. 23, 2016.

MONTEIRO, A.N.T.R. et al. The impact of feeding growing-finishing pigs with reduced dietary protein levels on performance, carcass traits, meat quality and environmental impacts. Livestock Science (in press), 
2017. Available from: <http://www.sciencedirect.com/science/article/ pii/S1871141317300525>. Accessed: Feb. 18, 2017. doi: 10.1016/j. livsci.2017.02.014.

MOSNIER, E. et al. Evaluation of the environmental implications of the incorporation of feed-use amino acids in the manufacturing of pig and broiler feeds using Life Cycle Assessment. Animal, v.5, p.1972-1983, 2011. Available from: <https://www.ncbi.nlm.nih. gov/pubmed/22440474>. Accessed: Jun. 20, 2014. doi: 10.1017/ S1751731111001078.

NATIONAL RESEARCH COUNCIL. Nutrients requirements of swine. 11.ed. Washingron: National Academy, 2012. 400p.

NELSON, D.L.; COX, M.M. Lehninger principles of biochemistry. WH Freeman. 6.ed. New York: Leningher, 2013. 1340p.

OGINO, A. et al. Life cycle assessment of Japanese pig farming using low-protein diet supplemented with amino acids. Soil Science and Plant Nutrition, v.59, p.107-118, 2013. Available from: <http:// www.tandfonline.com/doi/abs/10.1080/00380768.2012.730476> . Accessed: Sept. 12, 2015. doi: 10.1080/00380768.2012.730476.

PAS2050. Specification for the assessment of the life cycle greenhouse gas emission of goods and services. British Standards Institute, London, 2011. 45p.

PRUDÊNCIO DA SILVA, V. et al. Variability in environmental impacts of Brazilian soybean according to crop production and transport scenarios. Journal of Environmental Management, v.91, p.1831-1839, 2010. Available from: <http://www.sciencedirect.com/ science/article/pii/S0301479710000964>. Accessed: Nov. 10, 2014. doi: 10.1016/j.jenvman.2010.04.001.

RECKMANN, K. et al. Environmental impact assessment methodology with special emphasis on European pork production. Journal of Environmental Management, v.107, p.102-109, 2012. Available from: <http://www.sciencedirect.com/science/article/pii/ S030147971200196X>. Accessed: Dec. 10, 2015. doi: 10.1016/j. jenvman.2012.04.015.

RIGOLOT, C. et al. Modelling of manure production by pigs and NH3, $\mathrm{N} 2 \mathrm{O}$ and $\mathrm{CH} 4$ emissions. Part I: animal excretion and enteric $\mathrm{CH} 4$, effect of feeding and performance. Animal, v.4, p.1401-1412, 2010a. Available from: < https://www.ncbi.nlm.nih.gov/pubmed/22444660>. Accessed: Jan. 10, 2015. doi: 10.1017/S1751731110000492.

RIGOLOT, C. et al. Modelling of manure production by pigs and $\mathrm{NH}_{3}$, $\mathrm{N}_{2} \mathrm{O}$ and $\mathrm{CH}_{4}$ emissions. Part II: effect of animal housing, manure storage and treatment practices. Animal, v.4, p.1413-1424, 2010b. Available from: <https:/www.ncbi.nlm.nih.gov/pubmed/22444661>. Accessed: Jan. 10, 2015. doi: 10.1017/S1751731110000509.

TOLEDO, J.B. et al. Effect of the reduction of the crude protein content of diets supplemented with essential amino acids on the performance of piglets weighing $6-15 \mathrm{~kg}$. Livestock Science, v.168, p.94-101, 2014. Available from: <http://www.scielo.br/ scielo.php?script $=$ sci arttext\&pid $=\mathrm{S} 1516-35982014000600301>$. Accessed: Aug. 24, 2016. doi: 10.1016/j.livsci.2014.07.006.

USDA. 2013. Livestock and Poultry: World Markets and Trade. 2014: Record Global Meat Trade. Available from: <http://apps.fas.usda.gov/ psdonline/circulars/livestock poultry.pdf $>$. Accessed: Sept. 20, 2016.

VAN DER PEET-SCHWERING, C.M.C. et al. Ammonia emissions from pig houses in The Netherlands, Denmark and France. Livestock Production Science, v.58, p.213-224, 1999. Available from: <http:// www.sciencedirect.com/science/article/pii/S0301622699000172>. Accessed: Aug. 14, 2015. doi: 10.1016/S0301-6226(99)00017-2.

VAN DER WERF, H.M.G. et al. The environmental impacts of the production of concentrated feed: the case of pig feed in Bretagne. Agricultural Systems, v.83, p.153-177, 2005. Available from: $<$ http:// www.sciencedirect.com/science/article/pii/S0308521X04000587>. Accessed: Aug. 17, 2016. doi: 10.1016/j.agsy.2004.03.005.

VAUTIER, B. et al. Accounting for variability among individual pigs in deterministic growth models. Animal, v.7, p.1265-1273, 2013. Available from: <https://www.ncbi.nlm.nih.gov/pubmed/23552345>. Accessed: Mar. 10, 2015. doi: 10.1017/S1751731113000554.

WEINER, D. et al. Urea and ammonia metabolism and the control of renal nitrogen excretion. Clinical Journal of the American Society of Nephrology, v.10, p.1444-1458, 2015. Available from: <https:// www.ncbi.nlm.nih.gov/pubmed/25078422>. Accessed: Apr. 03, 2016. doi: $10.2215 /$ CJN.10311013. 